\title{
Education Needs of Internally Displaced Children in Afghanistan: A Needs Assessment Survey
}

\author{
Shahnaz Qayumi, Sahar Habib, Aziz Acceer, Ahamad Zahir Faqiri, Maxim Kuznitsof, \\ Sataruddin Sediqi, Karim A. Qayumi
}

Partnership Afghanistan-Canada (PAC) Center of Excellence for Education and Innovation, Faculty of Psychology \& Education Science, Kabul University, Kabul, Afghanistan

Email:shahnaz.qayumi@gmail.com

How to cite this paper: Qayumi, S., Habib, S., Acceer, A., Faqiri, A. Z., Kuznitsof, M., Sediqi, S., \& Qayumi, K. A. (2020). Education Needs of Internally Displaced Children in Afghanistan: A Needs Assessment Survey. Creative Education, 11, 524-544. https://doi.org/10.4236/ce.2020.114039

Received: March 16, 2020

Accepted: April 11, 2020

Published: April 14, 2020

Copyright ( 2020 by author(s) and Scientific Research Publishing Inc. This work is licensed under the Creative Commons Attribution International License (CC BY 4.0).

http://creativecommons.org/licenses/by/4.0/

\begin{abstract}
There is consensus that 40 years of war created an illiteracy gap in the education of children and parents in Afghanistan. Education was not considered to be amongst the primary need of the population particularly amongst those who have been displaced from their home due to security reasons and living in extremely harsh conditions in and around major cities of Afghanistan. It is obvious that this gap will have a subsequent negative effect on the future Afghan generations. There are also concerns that the parents of the children in these internally displaced refugees may be opposed to the education of their children and may not be open to receiving knowledge through technological advances. Therefore, the objective of this study was to survey Afghan parents and children in internally displaced camps with the following specific aims: to assess the needs for schooling in these camps; the willingness of parents to allow their children to go to school; the willingness of children to attend the schools; the level of support for education of children from the Government of Afghanistan Non-Governmental Organizations (NGOs) and to determine how familiar internally displaced Afghan children are with digital technology and how open they are to accept delivery of knowledge by electronic advances. A questionnaire was designed and distributed amongst 160 parents and 160 children in 10 internally displaced comps in and around the city of Kabul in Afghanistan. Results of the survey show that the Government of Afghanistan does not provide education for these children directly, however, they are very supportive of NGOs to provide this type of support. The survey also shows that the number of NGOs activities in this field is very limited and inconsistent. Results also demonstrated that $99 \%$ of the parents and children in these internally displaced camps are pro-education and they pledged their
\end{abstract}


unconditional support to any schooling initiative that would take place in these camps. The majority of children are not familiar with digital technology but are very curious to receive education through digital technology. It is concluded that internally displaced children in Afghanistan are ready and looking forward to going to school and there is an urgent and immediate need to support these children in order to fill in the education gap and prevent the social consequences related to this gap.

\section{Keywords}

Education, Needs Assessment, Internally Displaced Children, Technology-Empowered Learning, Afghanistan

\section{Introduction}

The Afghanistan government has achieved many successes, particularly in the education of K-12 students. The Afghan government, with help from the international community, has reached $50 \%$ of the mandate of education by building and operating schools (UNESCO, 2018). Most of these achievements, however, are to support middle-high income populations of Afghanistan children. According to the UN statistics, one third of Afghan children (3.7 million) are not attending school (USAID, 2019). Afghan children deprived from schooling can be divided in the following major categories: children in labor, street children, children below the poverty line and internally displaced children. Most of these children are under the radar of the government of Afghanistan or any international NGOs, working in Afghanistan to achieve success in the school education and other education mandates in Afghanistan (UNICEF, 2018).

Amongst these four categories, internally displaced children are a new phenomenon, related to the legacy of 40 years of war and destruction all over Afghanistan. War and insecurity have changed the geo-social structures and social landscape of Afghans particularly in recent years. Many Afghans were forced to move from their place of birth to major cities such as Kabul, Herat, Mazar Sharif, Jalal Abad and others, mainly due to security reasons. The number of these internally displaced people, also called internal refugees, is estimated around 2.5 million and 380,000 of them are around the city of Kabul (Internal Displacement Monitoring Center, 2019a). It is estimated that 58\% of the internal refugees are children (Internal Displacement Monitoring Center, 2019b). By nature, these children are strong, smart and have survived the harsh political and socioeconomical climate in Afghanistan, but do not have the social support to reach their full potential. These children are not born poor and most of them have attended school in their place of origin, but mainly due to security issues they were forced to leave their place of origin and could not receive any education in the new environment. They may die on the streets from violence, abuse, disease, drugs, malnutrition, hunger, harsh climates conditions and others. They 
may also use their physical and mental talents to serve the criminal circles or extreme ideologies and become a liability to the Afghan and international community (UNICEF, 2019a, 2019b; Bhutta \& Dewraj, 2002).

Years of longstanding war have created illiteracy gap in the education of children and parents in Afghanistan. Education is not considered to be amongst the primary needs of the population, particularly amongst those who have been displaced from their home due to security reasons and live in extremely harsh conditions in and around major cities of Afghanistan. It is obvious that this gap will have subsequent negative effect on the future Afghan generations. There are also concerns that the parents of the children in these internally displaced refugees may oppose to the education of their children and may not be open to receiving knowledge through technological advances.

Therefore, the objective of this study was to conduct a needs assessment survey of Afghan parents and children in internally displaced camps with the following specific aims to assess:

1) The need for schooling of children in these camps

2) The willingness of parents to allow their children to go to school

3) The willingness of children to attend the schools

4) The level of support for education of children from the Government of Afghanistan NGOs

5) The familiarity of internally displaced Afghan children with digital technology and their willingness to accept delivery of knowledge through digital technology.

\section{Methods}

\section{Participants}

Participants were representatives from 160 households living in 10 internal refugee camps in and around the city of Kabul (Figure 1 and Table 1). In these households, 160 adults and 160 children were interviewed (a total of 320 persons). In addition, we interviewed a Ministry of Education of the Afghan Government representative, the Commissioner for internally displaced children in Afghanistan. In this project we also interviewed 20 leaders/elders of the camps independently.

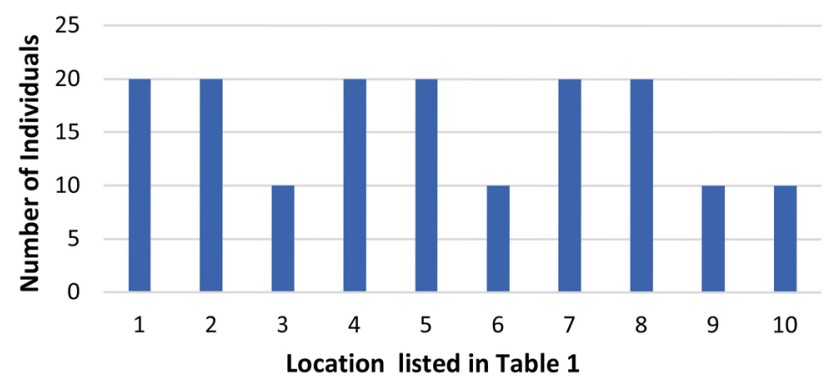

Figure 1. Population and location. Note: Number of displaced families surveyed in each of the camp sites included in the study and the location of the displaced families in camp sites in and around the Kabul city Afghanistan. 
Table 1. Location sites.

\begin{tabular}{cc}
\hline X axis \# & Camp Location \\
\hline 1 & 5th Dist, Dewanbigee refugees' compound \\
2 & 5th Dist, Helmandi refugees' compound \\
3 & 5th Dist, Refugee compound \\
4 & 5th Dist, Qala-e-wazeer refugees' compound \\
5 & 4th Dist, Chaman Babrak refugees' compound \\
6 & 4th Dist, Char Rahee Gule Surkh refugees' compound \\
7 & 8th Dist, Kart-e-naw, 1st refugees' compound \\
8 & 8th Dist, Bagramee, Husainkhil 1st refugees' compound \\
9 & 8th Dist, 2nd Kunduzi's refugees' compound \\
10 & 8th Dist, 3rd refugees' compound \\
\hline
\end{tabular}

Note: Table 1 shows the location of the sites. The numbers correspond to the numbers on $\mathrm{X}$ axis of the Figure 1.

\section{Instruments}

For the purposes of the study, the following two questionnaire forms were developed:

1) Government, NGOs Representative Form-included the questions regarding the participation of the Government and NGOs in the education of internally displaced children. The respondents for this section were Government officials, NGO representatives and 20 Leader/elders from these camps. The questionnaire with specific questions is presented in Appendix 1.

2) Parents and Children Form-This form contained all the questions asked to children and parents and had three sections:

- Demographics

- Questions to be answered by children

- Questions to be answered by Parents

This questionnaire with specific questions is presented in Appendix 1.

Since some of the respondents in these camps were illiterate, responses to the survey questions were collected by trained interviewers. The team consisted of Kabul University Department of Psychology and Science of Education graduate students supervised by our experienced project manager (A A) who was also responsible for training of the interviewers and the quality assurance in data collection. Interviewers carried out the interviews with parents and children separately. They explained the questions to participants to make sure they were confident in the answers provided for the survey questions, and that there was no misunderstanding or misperception.

\section{Procedure}

Six graduate students from the Department of Psychology and Education Science at Kabul University were recruited as research assistants. These research assistants were trained to explain the objectives and procedures of the study, to 
elicit agreement/or disagreement to participate, and to assist the completion of the questionnaire. They were also prepared to answer common questions by respondents.

Conditional on expressed agreement to participate, the questionnaire was administered by the interviewer, usually immediately after obtaining consent. The questions were read, and the answers were recorded by the interviewer, who also provided explanations (but not suggestions for the answer) if the questions were not clear. Government officials and NGO representatives were approached individually through official channels. During the interview their responses were audio-recorded.

\section{Analyses}

The demographic information was summarized by descriptive statistics. Th results were compared to statistics from other national or international documents and surveys $(1-6,11)$. Descriptive statistics were used to build profiles for each value related to the objectives of this study in each study section.

\section{Results and Discussion}

\section{Part one: Parents response:}

In this study 160 internally displaced heads of the families, in 10 internal refugee camp sites in and around the City of Kabul were interviewed. In the 160 heads of the families, 135 were male and 25 females. The youngest person in the group was 20 years of age and the oldest person was 75 years old. The specific age categories are depicted in Figure 2.

The majority of these families are coming from the south and south-eastern provinces of Afghanistan, including Laghman $26.8 \%$ (43), Ningrahar 13.7\% (22), Helmand $12.5 \%$ (20), and other provinces (Figure 3).

In addition to internally displaced families, a small number of families $7.5 \%$ (12) arrived from Pakistan and the rest from other provinces of Afghanistan, such as Parwan, Kapisa, Balkh and Logar. Amongst 160 families interviewed 92 (57.5\%) families spook Pashto, 66 (41.2\%) Dari and 2 (1.2\%) Anko. All families were located in ten internal refugee camps. The name of the camps with the number of families in each camp is presented in Table 1.

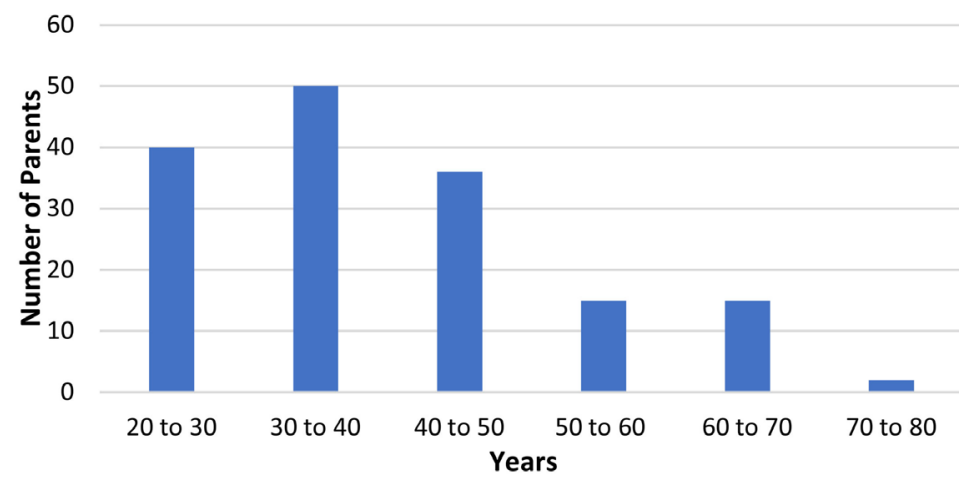

Figure 2. Adult age distribution. Note: Show parents' age distribution and the number of parents each in six age categories. 


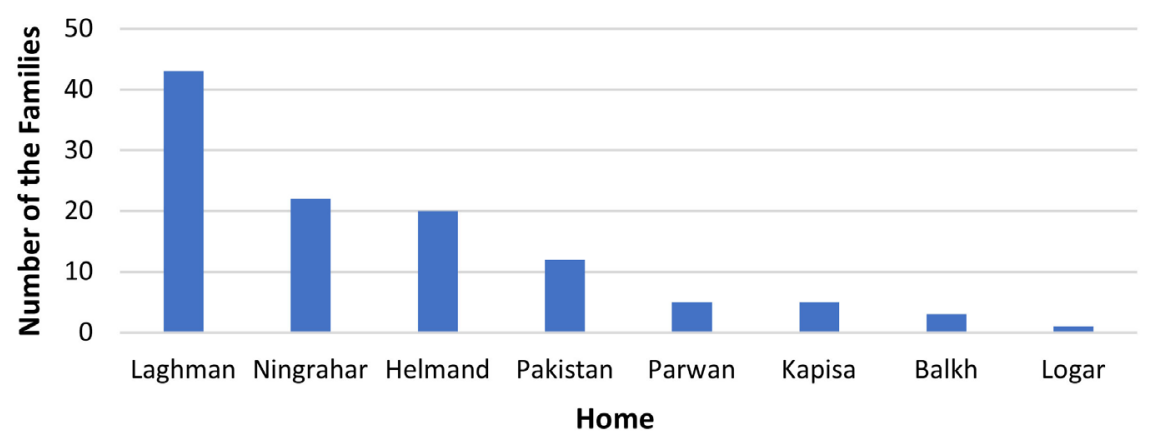

Figure 3. Origin of the population. Note: Figure 3 shows the districts of Afghanistan from where the refugees originated.

The vast majority $83.7 \%$ (134) of the family heads were illiterate. Amongst the $16.3 \%$ who could read and write, only one person had education above elementary school, with the rest having different levels of elementary school education.

$56.2 \%$ (90) of family heads were jobless. Of those employed, some were doing low-level labor such as shoe polishing or car washing, while others were day-laborers. There was an average of 4 school-age children per family, varying from 4 to 16 years of age. $87 \%$ of the families reported their reason for migration was security, and $13 \%$ were in search of a job, economic prosperity, or other reasons (Figure 4).

A good portion of this need's assessment was focused on the value of education for this group of refugees and the willingness of parents to support a school. Individuals and families in this group came from remote villages in Afghanistan. Therefore, the perception was that the opinion of the heads of the families regarding education, particularly education via electronics, would be negative, or at least divided. The results of this survey showed that, on the contrary, the absolute majority (99\%) of parents are in favor of education in general and education delivered by electronic means. Only $1 \%$ of those surveyed were opposed education (Figure 5).

When asked why school is important to them, $94 \%$ responded that education would help their children to become open-minded, $3 \%$ of parents wanted their children to be able to read and write and $3 \%$ to become knowledgeable (Figure 6).

Parents also have dreams for their children. About $37 \%$ of respondents want their children to have a better life, $12 \%$ want their children to be literate, and $6 \%$ to become doctors. The rest of the responses are divided into other professions such as engineers, priests, and others. It is interesting to know that $6 \%$ of parents don't want their children to end up like them. The results of this study clearly show that the majority of parents in these camps have a clear understanding of why education is important and why they want their children to go to school. Further investigation revealed that the $1 \%$ of parents opposed school attendance are not against the education but are opposed because the children are the breadwinners of the family. 


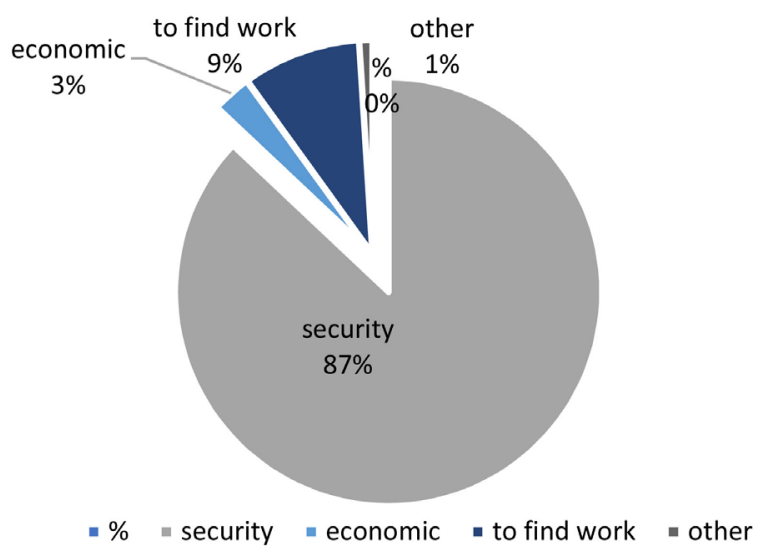

Figure 4. Reason for displacement. Note: Figure 4 shows the reason for migration. The majority of the families moved due to security issue.

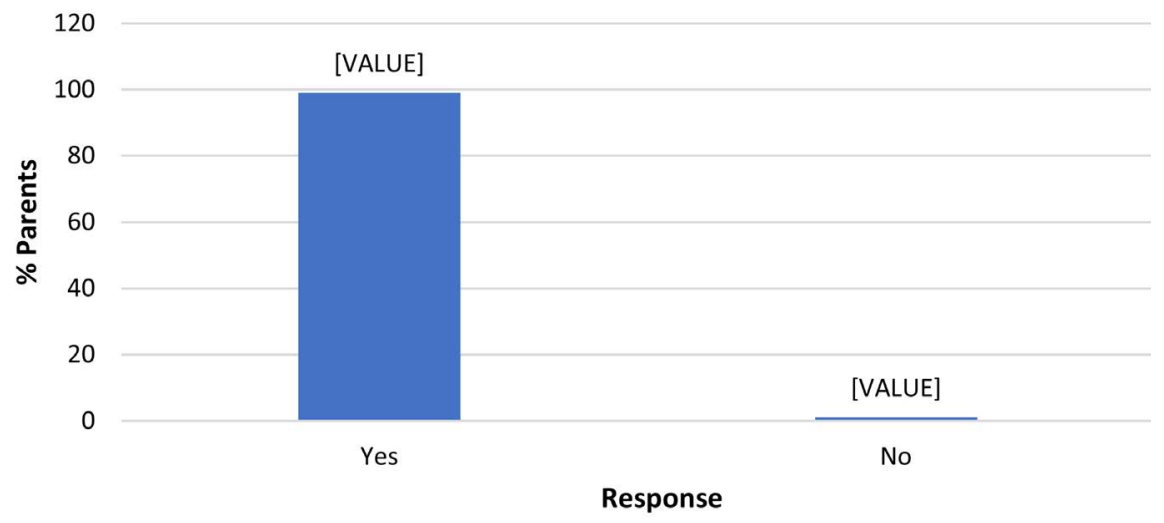

Figure 5. Education support. Note: Figure 5 shows that the vast majority of parents are willing to send their children to school and support a school.

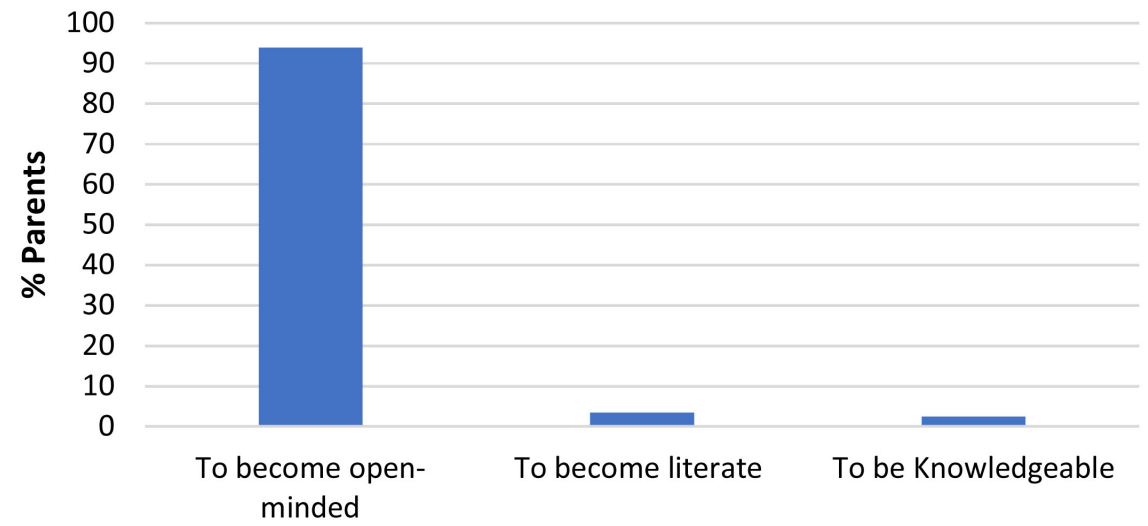

\section{Response}

Figure 6. Reason for support. Note: Figure 6 shows that parents have a clear understanding of why school is important for their children.

In this survey, it was important for us to gather parents' ideas on how they plan to support a school in their community. The results of our survey for this question were very encouraging. Parents in these internally displaced camps, 
who are in very tough conditions and are in survival mode, came up with some specifics to support the schools for their children. A summary of their comments is presented in Table 2 and Figure 7.

\section{Part two: Children's Response}

In the second part of study, 160 children between the ages of 4 and 16 from the same 10 camp sites participated one-to-one interviews using the described standard questionnaire designed for this study (Figure 8).

Seventy two percent of the children available for interview were male (72\%) and twenty eight percent were female (28\%) (Figure 9).

Results of the study demonstrated that $75 \%$ of children did not attend the school in their place of origin, and only $25 \%$ attended school prior to migration. Twenty-five percent of children interviewed are the bread winners of the family and are doing domestic work and other labor to earn money. Nine percent are in the labor force to support their families. The rest of those interviewed (66\%) stay home but perform domestic work in their own household to support the family.

In this part of the survey, it was out most important for us to know if children would like to go to school. Again, it was very encouraging and surprising that the opinion of $94.3 \%$ (151) of the children in these refugee camps was, "Yes, I want to," and only 5.6\% (9) said, "No, I do not want to" (Figure 10).

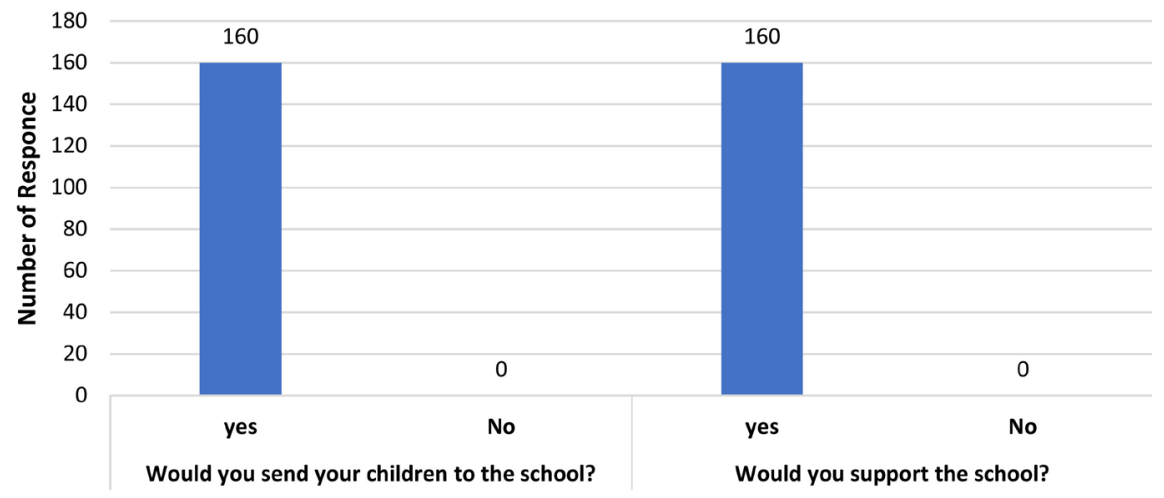

Figure 7. Commitment to support education.

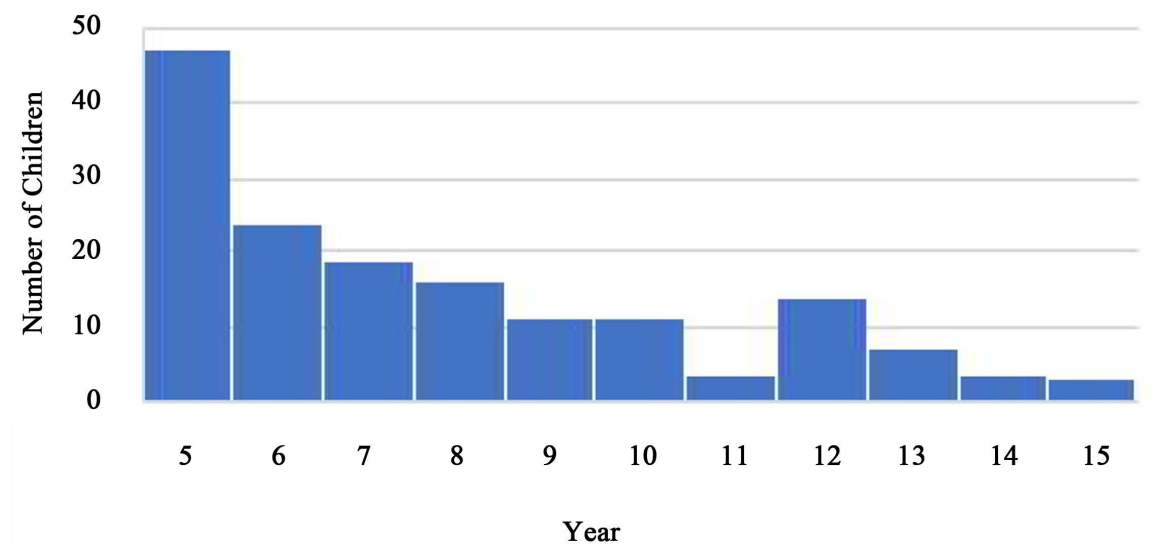

Figure 8. Children age distribution. 


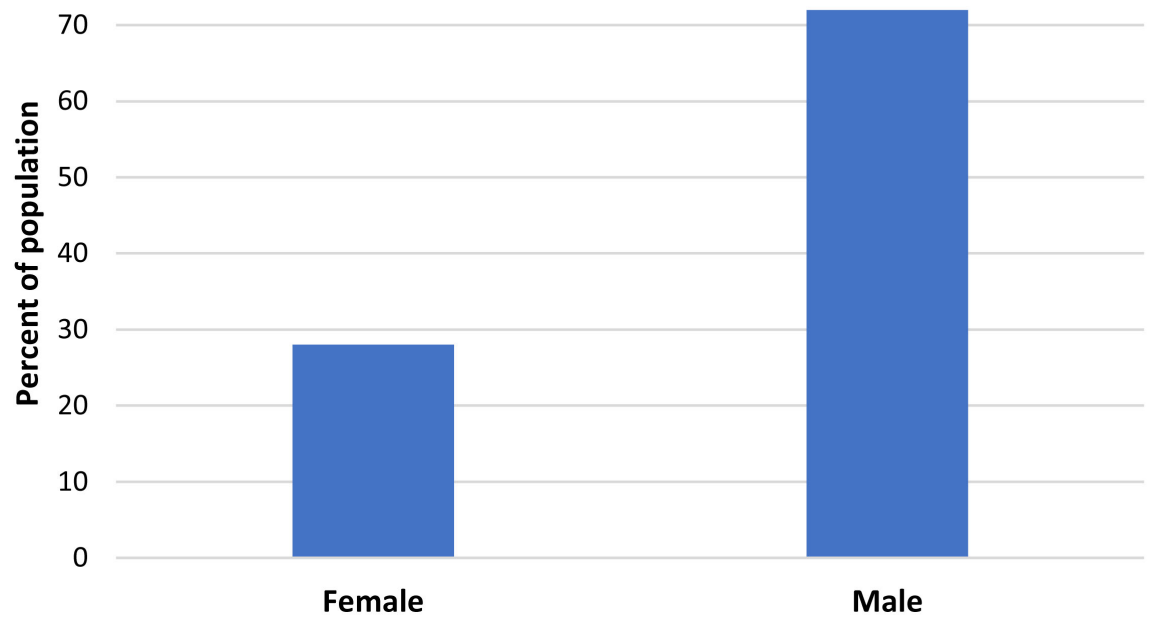

Figure 9. Children gender distribution.

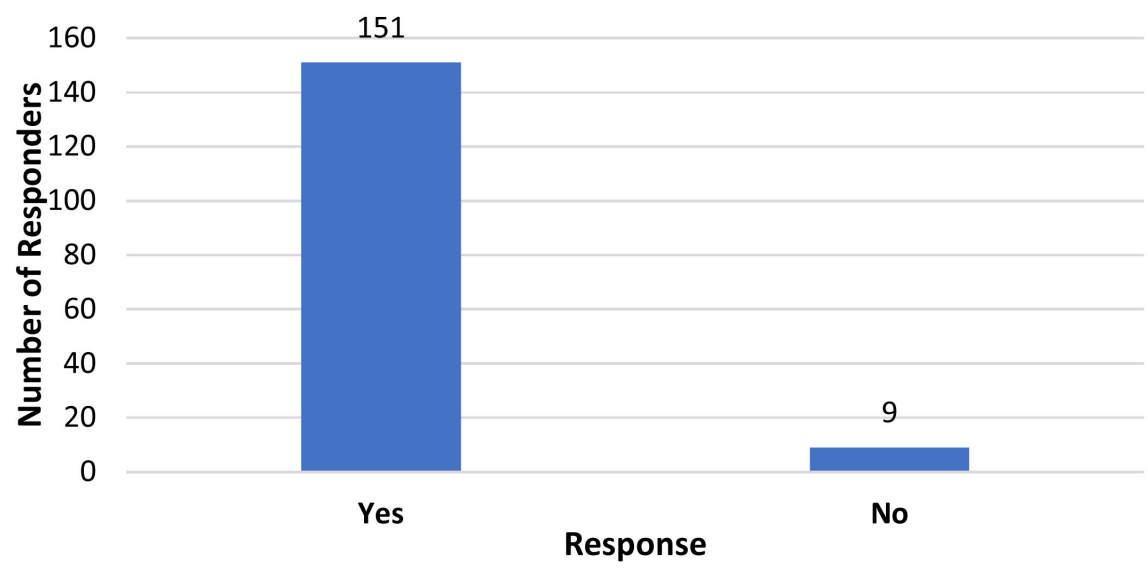

Figure 10. Children interest for education.

Table 2. Ways to support education.

\begin{tabular}{ccc}
\hline Ways proposed by parents & No & $\%$ \\
\hline I encourage my children to study and go to school & 62 & 39 \\
I make sure they attend the school & 55 & 34 \\
I buy pen, notebook and some other material & 24 & 15 \\
I will provide security for the school & 11 & 7 \\
I will do any task which is given to me & 7 & 4 \\
I clean the class & 1 & 0.6 \\
Total & 160 & 100 \\
\hline
\end{tabular}

To further explore this question, we asked for the reason behind the child's "yes" or "no." Results of the "yes" and "no" as well as the reason behind the answer is depicted in Table 3. The "No" response from the nine children correlates with the age of children. "No, because the school is far," "No, because I do not 
Table 3. Children rational for education.

\begin{tabular}{lc}
\multicolumn{1}{c}{ Why do you like to go to school? } & Answer \\
\hline Yes, to become literate, and gain knowledge & 80 \\
Yes, because I like studying and going to school & 41 \\
Yes, to have good life in the future & 11 \\
Yes, to get good job solve my problems & 6 \\
Yes, because all the children and my relatives are going to school & 6 \\
Yes, I study to become a doctor & 2 \\
Yes, I just like the school & 2 \\
To learn something & 3 \\
No, because the school is far & 3 \\
No, because I do not like school & 2 \\
No, because there is nobody else to work and earn money and afford the expenses & 2 \\
No, because the weather is too cold & 2 \\
Total & 160 \\
\hline
\end{tabular}

like school," and "No, because the weather is too cold" all correlate with ages 4 6. "No, because there is nobody else to work and earn money and I cannot afford the expenses" correlates with ages $14-16$.

It was in the scope of our interest to find out if children in these camps with harsh living conditions and no foreseeable future, had a dream about their future. We were surprised to find out that every child in these camps has a dream of becoming a highly trained professional such as a doctor, engineer, or teacher. Some also aspire to be members of the parliament or ministers and two of them would like to be the president of Afghanistan Table 4.

Since PAC (Partnership Afghanistan Canada) is planning to deliver the school program using technological advances, it was important for us to understand the level of familiarity, knowledge, experience and willingness of these children using electronic gadgets such as computers, tablets and other electronic communication devises.

In this context the first question we asked was about their knowledge and familiarity with computers and/or other electronic devises. About $50 \%$ of the children (80) have some knowledge about the computers, digital phones, or other devices and the other 50\% doesn't have any knowledge about computers or digital media. Of the 80 students who claimed about computers only $20 \%$ (33) expressed how they received the knowledge and what computers can do. Their responses are summarized in Table 5.

Since the absolute majority want to go to school, half of them are not familiar with electronic devices, and $84 \%$ of them don't have knowledge of computer games, we were very curious to know if there is any interest to learn with computers. To determine this, we asked the following questions: 
Table 4. Children's dream for the future.

\begin{tabular}{|c|c|c|}
\hline Profession & Number & Percent \\
\hline Doctor & 35 & 21.875 \\
\hline Engineer & 17 & 10.625 \\
\hline Teacher & 32 & 20 \\
\hline Police & 13 & 8.125 \\
\hline Car seller & 1 & 0.625 \\
\hline Literate & 2 & 1.25 \\
\hline Pilot & 5 & 3.125 \\
\hline Mullah & 5 & 3.125 \\
\hline Director of Company & 1 & 0.625 \\
\hline Receptacle & 6 & 3.75 \\
\hline Athlete (Karate) & 2 & 1.25 \\
\hline Reader of the holy Qur'an & 2 & 1.25 \\
\hline Big man Important man & 2 & 1.25 \\
\hline Driver & 6 & 3.75 \\
\hline Traffic & 3 & 1.875 \\
\hline To get a job & 2 & 1.25 \\
\hline Shopkeeper & 3 & 1.875 \\
\hline Government employee & 1 & 0.625 \\
\hline Powerful person & 1 & 0.625 \\
\hline Parliament representative & 1 & 0.625 \\
\hline President & 2 & 1.25 \\
\hline University student & 1 & 0.625 \\
\hline Did not answer & 0 & 0 \\
\hline Commander & 2 & 1.25 \\
\hline Mother & 4 & 2.5 \\
\hline School principal & 2 & 1.25 \\
\hline Nothing & 4 & 2.5 \\
\hline Business & 2 & 1.25 \\
\hline Electrician & 1 & 0.625 \\
\hline Minister & 2 & 1.25 \\
\hline Total & 160 & 100 \\
\hline
\end{tabular}

Table 5. Children's familiarity with technology.

\begin{tabular}{cc}
\hline Children Answer & $\#$ \\
\hline My father's friend had computer & 1 \\
Computer is something good, it facilitates the work & 1 \\
We can calculate by computer & 2 \\
My cousin had computer & 2 \\
\hline
\end{tabular}




\section{Continued}

\begin{tabular}{ll}
$\begin{array}{c}\text { The tablet is bigger than a mobile } \\
\text { The computer and internet can do lots of work } \\
\text { Compute is like T. V } \\
\text { My uncle had Tablet } \\
\text { On T. V }\end{array}$ & 2 \\
$\begin{array}{ll}\text { Game can be played on computer } \\
\text { Everything is done by computers } \\
\text { We can study by tablet }\end{array}$ & 4 \\
In the shop, city and people hand & 5 \\
Anything can be written in computer & 5 \\
Total Number of children with some understanding of computers and electronics & 33 \\
\hline
\end{tabular}

1) Do you like to learn about computers, electronic tablets, Internet?

2) Do you like to play computer games?

3) Do you like to learn through games?

4) Do you know anything about the computers, electronic tablets, Internet?

5) Did you use any electronic game?

Note: the number of these questions responds to the numbers on the $\mathrm{X}$ axis.

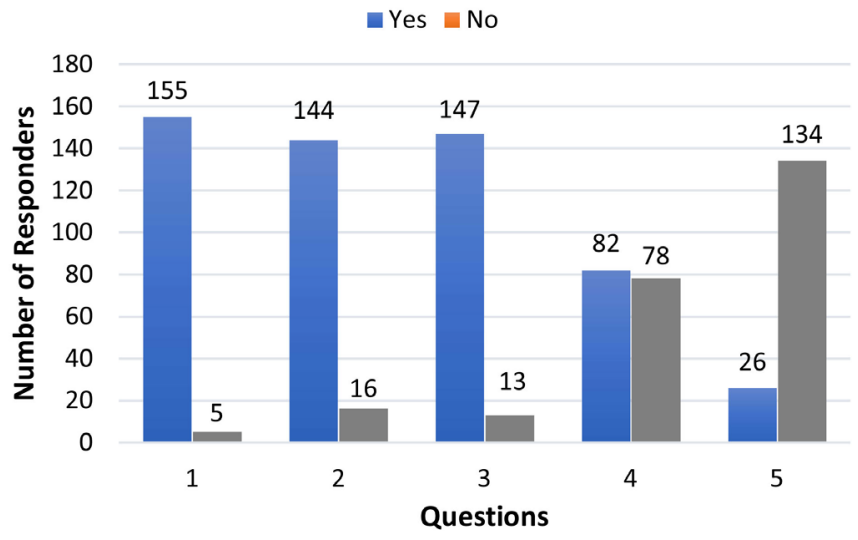

Figure 11. Children's interest learning through technology.

It is evident from this study that the majority (96\%) of children, whether they are familiar with computers or not, are curious and would like to learn about them, while only $3 \%$ are opposed the idea. Furthermore, the majority of children in this study also like to play computer games and learn through computers.

In this study, we wanted also to establish facts on the dietary condition of children. For this purpose, we asked questions about their food and water intake. The results of this investigation showed that the main source of food for children in these camps is vegetables and fruits. Carbohydrates are second most consumed, and proteins are the lowest in their daily diet. The majority of children have a sufficient amount of water intake, about $750 \mathrm{ml}$ of water per day. 


\section{Part three: Camp leaders, NGOs and Government response:}

In the third part of this study we collected some data from the leaders of the camps, NGOs, and the Government of Afghanistan on the level for support, kind of support, and value of support for education of internally displaced children.

The government representatives and leaders of the camps who were interviewed agreed that the Afghan government does not have the capacity to provide any direct support for support the education of Internally Displaced Children. The government's support is mainly through NGOs. According to the Afghan government, so far more than 3 Million AFN ( $\$ 38,000$ US dollars) have been used for the education of internally displaced camps in the following specific projects:

1) $\mathrm{CHF}$ (Common Humanitarian Fund)

2) ECW (Education Cannot Wait)

3) SIDA

4) $\mathrm{ECHO}$

5) BMZ

6) Save the Children

The specific written comment from the government authorities to our survey team can be summarized as follows: "The Ministry of Education has an active and dedicated team that Save the Children and the UN are members of the board. We have almost 20 partners including national and international organizations and a meeting is being held monthly. We discuss all about education of displaced Afghans and observe the projects. In addition, we are working on future plans and sharing issues with the members of the board. The Education in Emergency board is trying to prepare a better and standard system for internally displaced Afghans in order to have access to education, for instance, we are working to standardize the system to teach them immediately anywhere, anytime and the organizations will follow the standard system whenever it is prepared."

The government and NGO survey responses revealed that specific classes provided for the past five years include C.B.E (Common Based Education) for children under 10 years old, A.L.P (Accelerated Learning Assessment) for children who are between 10 - 15 years old and T.L.C (Temporary Learning Assessment) for all ages in internally displaced Afghan camps. These programs are financially supported by non-governmental organizations backed by the Afghan government.

This research further reviled that these programs do not have a unified curriculum specifically designed for these conditions. The education content (syllabus) includes the Afghan encyclopaedia and some version of the literacy content approved by the government of Afghanistan. Most of these programs are vocational skill programs designed for children over 12 years of age. The ministry responsible for the education of these children is the Ministry of Education, not the Ministry of Refugees. 


\section{Conclusion}

In conclusion, the results of this study show that the education gap for children in the internally displaced camps in and around Kabul city is a reality and, despite the efforts of the Afghan government and other international NGOs, the least attention is paid to children's elementary education. Therefore, there is an urgent need to support the education sector in these refugee camps. Results of our study correlate with the findings of other national and international researchers $(1-6,11)$. All studies are emphasizing on the scale of internally displaced children and express concern for the generation of uneducated children becoming a member of our society.

The uniqueness of our study includes data related to the perception that parents in these camps may not want their children to go to school or the children who may not want to attend school is not evidence-based. The results of this study demonstrate that the vast majority of parents would like to have a school in their camp for their children to attend. Furthermore, they are willing to participate and support the school every way they can. It also shows that the majority of children are very enthusiastic about learning and attending school, particularly if the school is within the premises of the camp.

It was also unique to this study to know that children and parents alike are well aware of the role of education in the formation of their future. Parents clearly understand why they should support education for their children, and they do have a dream for their children's future. It is also evident that despite the lack of knowledge about the computers and other electronic devices used for education, children in these camps would like to explore the opportunity to learn from digital equipment, particularly when a gamified education process is used. Most NGOs are using nutritional products to support the education of deprived children. This study showed that for these refugee camps, supplementation through nutritional products, particularly protein, is important.

Displacement has become a persistent, on-going feature of the 21st century; so, it is vital to be prepared and develop a lasting capacity to deal with displacement wherever it occurs and endorse policies that support and enable new ways to learn. As governments, international agencies and Non-Governmental Agencies struggle to ensure these children a safe learning environment and a good quality education, many looks to information and communications technology (ICT) to provide at least part of the solution. The use of smartphones and other mobile devices, universal even among needy refugees, can provide a platform that educators can influence to reach marginalized children and youth (Education Global Practice MENA (GED05), 2016).

Norwegian government funded the EduApp4Syria competition which requested to develop an open source smartphone application that could build foundational literacy skills in Arabic and recover psychosocial well-being for Syrian refugee children. An estimated 2.3 million Syrian children had been out of school because of violent conflict in their country. These children are primar- 
ily displaced within Syria; living as refugees in Lebanon, Jordan, Iraq, and Turkey; or in transit camps in countries like Greece and Italy (Antura, 2017).

The Norwegian Agency for Development Cooperation (Norad) coordinated the competition in collaboration with Norwegian University of Science and Technology; All Children Reading: A Grand Challenge for Development (ACR GCD) - a partnership of the United States Agency of International Development (USAID), World Vision, and the Australian Government; mobile operator Orange; and the Inter-Agency Network for Education in Emergencies (INEE). Two games were qualified as winners through the two-phased competition: Antura (developed by Games without Border and the Letters) and Feed the Monster (developed by as joined venture between Apps Factory and the Center for Educational technology and the International resource committee) (Antura, 2017). We believe that our study supports the notion of using technology for the education of internally displaced and refugee children. There is also a belief that the use of technology is good to have for a fast start and a robust achievement. However, it would be necessary to transfer these children, for further education, to a regular school environment where a teacher motivates and facilitates learners to obtain skills more relevant to their needs, and develop critical and creative thinking and problem-solving skills as well as other higher-order thinking skills (UNESDOC, Digital Library Education, 2018).

We recommend that NGOs support the education sector of the internally displaced children in Afghanistan by providing the educational environment, curricula, and materials, particularly when it relates to the use of digital media. Collaboration and cooperation of the government, NGOs, and businesses are required to eradicate illiteracy amongst deprived children in Afghanistan, including internally displaced children.

\section{Acknowledgements}

We acknowledge the support of the Kabul University Faculty of Education, UBC Faculties of Education and Medicine, UBC Institute for Asian Studies and volunteer students, Blue Afghanistan Research Center. Special thanks to Dr. George Pachev for Review and feedback.

\section{Conflicts of Interest}

The authors declare no conflicts of interest regarding the publication of this paper.

\section{References}

Antura (2017). https://www.antura.org/impact/

Bhutta, Z. A., \& Dewraj, H. L. (2002). Children of War: The Real Casualties of the Afghan Conflict. https://www.ncbi.nlm.nih.gov/pmc/articles/PMC1122273/

Education Global Practice MENA (GED05). (2016). ICT and the Education of Refugees: A Stocktaking of Innovative Approaches in the MENA Region. 
http://documents.worldbank.org/curated/en/455391472116348902/pdf/107997-WP-P1 60311-PUBLIC-ICT-and-the-Education-of-Refugees-final.pdf

Internal Displacement Monitoring Center (2019a). Afghanistan Drought Displaced as Many as Conflict.

http://www.internal-displacement.org/countries/afghanistan

Internal Displacement Monitoring Center (2019b). Escaping War: Where to Next. http://www.internal-displacement.org/countries/afghanistan

UNESCO ( 2018). Global Education and Monitoring Report. https://unesdoc.unesco.org/ark:/48223/pf0000265866

UNESDOC, Digital Library. Education (2018). A Lifeline to Learning: Leveraging Mobile Technology to Support Education for Refugees. https://unesdoc.unesco.org/ark:/48223/pf0000261278

UNICEF (2018). All Children in School and Learning Global Initiative on Out-of-School Children Afghanistan Country Study.

https://www.unicef.org/afghanistan/media/2471/file/afg-report-oocs2018.pdf.pdf

UNICEF (2019a). Humanitarian Action for Children, Afghanistan. https://www.unicef.org/appeals/afghanistan.html

UNICEF (2019b). Preserving Hope in Afghanistan, Protecting children in the world's most lethal conflict. https://www.unicef.org/afghanistan/media/4196/file/English.pdf

USAID (2019). Country Development Cooperation Strategy FY-2019-2023. https://www.usaid.gov/sites/default/files/documents/1871/CDCS_Afghanistan_Nov_20 23.pdf 
Appendixes

Appendix 1. Interview Instrument

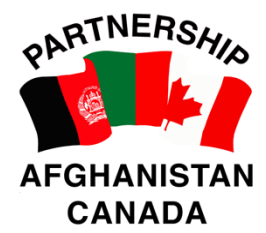

Needs Assessment Survey for Internally Displaced Children in Afghanistan Provided by:

\section{Partnership Afghanistan Canada (PAC)}

Correspondence address:

Vancouver BC

2018

\section{Objective of the survey:}

The objective of this needs assessment is to study the extent of the problems related to the education of internally displaced children in Afghanistan, and to understand what kind of support the Government of Afghanistan and other NGO's in the international community, provides to support the education of Internally Displaced (IDC) Children in Afghanistan.

The primary specific aims of this survey are to identify if the Government of Afghanistan, or other international organizations, are helping the education of Internally Displaced Children in and around Kabul City; to see if there is interest from the IDC, families and the community for the education of their children; To identify if they are willing to support this type of project in their camps; and to see if the children would have interest for learning through an electronic platform and education through games. The secondary specific aim is to identify if incentive, such as food, would provoke more interest in parents and students to learn. Therefore, to provide meaningful data questions are divided into the following four categories:

A. Demographics

B. Questions related to the Government of Afghanistan/other NGOs

C. Questions related to the heads of displaced families

D. Questions related to the displaced children aged 3 - 13 and other youth interested to get education

\section{A. Demographics}

Name of the head/s of displaced Family
Name of the student
Location
Contact Number
Age
Gender
Language
Education level




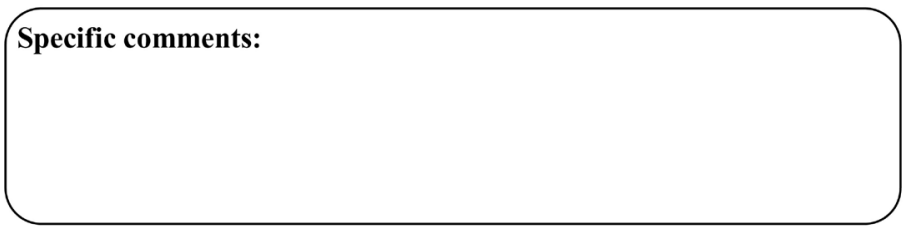

B. Questions related to the Government of Afghanistan/other NGOs/Older authorities.

1) Does the Afghan Government support the education of Internally Displaced Children? Yes

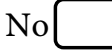

If the answer is yes, please answer the following questions:

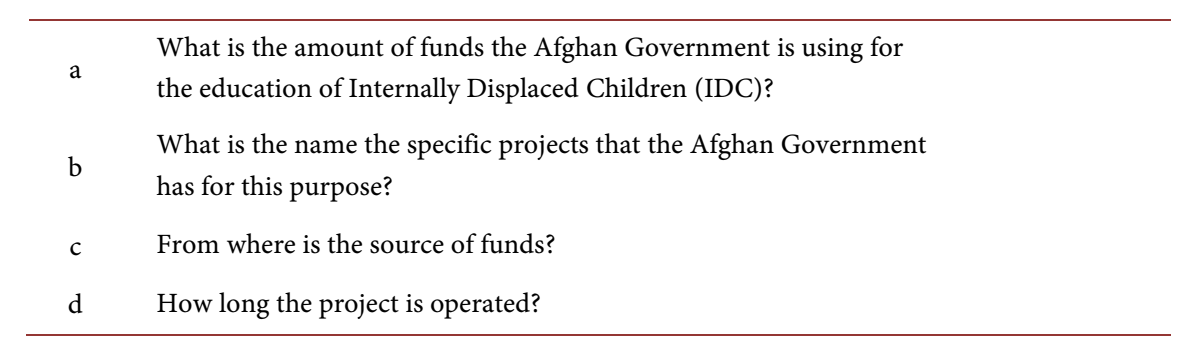

\section{Specific comments:}

2) Is there a measurable impact? Yes

No

If yes, please describe the outcome and short-term impacts:

\begin{tabular}{cc}
\hline Improvement & Description \\
\hline Outcome & \\
Short-term impacts & \\
Not measured & \\
\hline
\end{tabular}

\section{Specific comments:}


3) Are there other agencies (NGOs) working on the education of Internally Displaced Children in Afghanistan? Yes No

If yes, please describe:

$\begin{array}{ll}\text { a } & \text { What is the name of the project? Please describe } \\ \mathrm{b} & \text { Who owns and operates the project? } \\ \mathrm{c} & \text { From where do they receive their funding? } \\ \mathrm{d} & \text { How long the project is operated? }\end{array}$

4) Is there a measurable impact? Yes

No

If yes, please describe the outcome and short-term impacts:

\begin{tabular}{cc}
\hline Improvement & Description \\
\hline Outcome & \\
Short-term impacts & \\
Not measured & \\
\hline
\end{tabular}

Specific comments:

\section{Questionnaire for Parents:}

\begin{tabular}{cl}
\hline 1 & \multicolumn{1}{c}{ Questions } \\
\hline 2 & Why did you move to Kabul? \\
3 & Where did you live before moving? \\
4 & How long ago did you move from your home? \\
5 & How many children do you have? \\
6 & Were they going to school back home? \\
7 & How old are they? \\
8 & Are they working? \\
9 & Do you want them to go to school? \\
10 & Why school is important for your children? \\
& What future do you want your children to have? \\
11 & $\begin{array}{l}\text { Send your children to the school } \\
\text { Support the school }\end{array}$ \\
& $\begin{array}{l}\text { How would you provide the support - please explain? } \\
\text { Make sure children go to that school }\end{array}$ \\
& $\begin{array}{l}\text { Provide security for the school and the students } \\
\text { Participate in the school activities }\end{array}$ \\
& Ensure the safety of children and school staff
\end{tabular}

\section{Questionnaire for Children:}

\begin{tabular}{lll}
\hline & & \multicolumn{1}{c}{ Questions } \\
\hline 1 & What is your name? & \\
2 & How old are you? & \\
3 & What do you do during the day? & \\
\hline
\end{tabular}




\section{Continued}

\begin{tabular}{ll}
\hline 4 & Do you like to go to school? \\
5 & Why do you like to go to school? \\
6 & Who would you like to be when you grow up? \\
7 & If we had a school in this place would you attend the school? \\
8 & $\quad$ Do you know anything about the computers, electronic tablets, \\
9 & Internet? Yes/No - If yes please describe. \\
10 & Do you like to learn about computers, electronic tablets, Internet? \\
11 & Did you use any electronic game? Yes/No - If yes please describe. \\
12 & Do you like to learn through games? \\
13 & What is your daily diet? \\
14 & How much water do you drink in a day? \\
15 & Would you like to have water and basic food in the school? \\
\hline
\end{tabular}

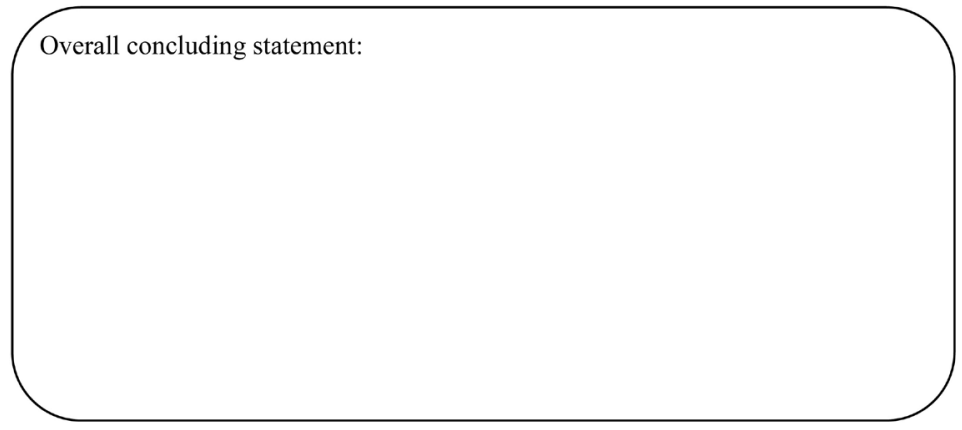

\section{Appendix 2. List of Older/Leader Individuals Interviewed from Identified Camp Sides}

\begin{tabular}{|c|c|c|c|c|c|}
\hline Number & Name & age & Gender & education & Camp address \\
\hline 1 & 01 & 52 & Male & 0 & 5th Dist., Dewanbigee \\
\hline 2 & 02 & 35 & Male & 0 & 5th dist., Helmandi \\
\hline 3 & 03 & 60 & Male & 0 & 5th dist., Helmandi \\
\hline 4 & 04 & 52 & Male & 0 & 5th dist., Helmandi \\
\hline 5 & 05 & 40 & Male & 0 & 5th dist., Helmandi \\
\hline 6 & 06 & 36 & Male & 0 & 5th dist., \\
\hline 7 & 07 & 35 & Male & 10 & 5th dist, Qala-e-wazeer \\
\hline 8 & 08 & 68 & Male & 6 & 5th dist, Qala-e-wazeer \\
\hline 9 & 09 & 28 & Male & 0 & 5th dist, Qala-e-wazeer \\
\hline 10 & 010 & 42 & Male & 0 & 4th dist, Chaman Babrak \\
\hline 11 & 011 & 40 & Male & 0 & 4th dist, Chaman Babrak \\
\hline 12 & 012 & 40 & Male & 6 & 4th dist, Chaman Babrak \\
\hline 13 & 013 & 58 & Male & 0 & 4th dist, Char Rahee Gule Surkh \\
\hline 14 & 014 & 65 & Male & 0 & 4th dist, Char Rahee Gule Surkh \\
\hline 15 & 015 & 48 & Male & 0 & 8th dist, Kart-e-naw \\
\hline 16 & 016 & 45 & Male & 0 & 8th dist, Bagramee, Husainkhil \\
\hline 17 & 017 & 58 & Male & 0 & 8th dist, Bagramee, Husainkhil \\
\hline 18 & 018 & 37 & Male & 0 & 8th dist, Bagramee, Husainkhil \\
\hline 19 & 019 & 58 & Male & 0 & 8th dist, 2nd Kunduzi's \\
\hline 20 & 020 & 54 & Male & 0 & 8th dist, 2nd Kunduzi's \\
\hline
\end{tabular}




\section{Appendix 3. Notes from the Older/Leader in the Camps and from Interviews with the Afghanistan Government}

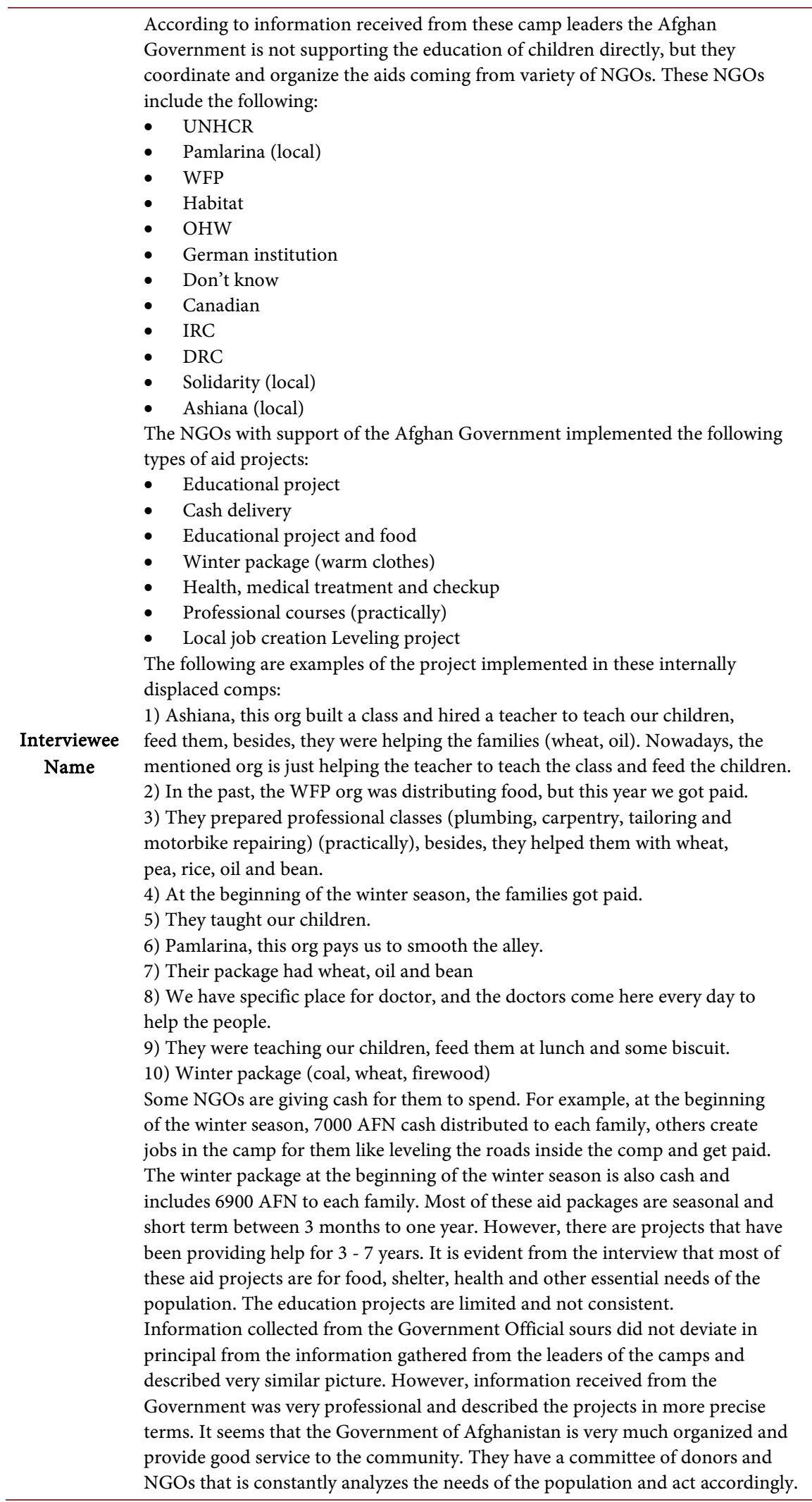

